\title{
The soft power of India Buddhism for the sustainable development in north East Asia
}

\author{
Thanh Hang Pham ${ }^{1, *}$ and Ekaterina Nikolaeva $^{2}$ \\ ${ }^{1}$ Institute of Religion and Belief, Ho Chi Minh National Academy of Politics, 135, Nguyen Phong Sac \\ Str., 10000, Nghia Tan Ward, Cau Giay District, Hanoi City, Vietnam \\ ${ }^{2}$ Chelyabinsk State University, 129, Br.Kashirinykh str., 454001, Chelyabinsk, Russia
}

\begin{abstract}
In the context globalization today, peaceful cooperation, mutual substainable development, avoiding conflict and confrontation is becoming the main trend in foreign policy of several countries and regions. Therefore, the use of cultural strength as a source of soft power to enhance the national image, power and position is particularly focused in international relations in the $21^{\text {st }}$ century. Buddhism is a major religion, which has a deep influence and popularity all over the world. Originating from India, Buddhism has spread to Eastern and Western cultures, it contributes to enriching the soft power of India. The development of Buddhism creates a cultural link between India and the world, helping to expand the influence of India by the power of culture and religious faith. Through Buddhism, people know and admire India as an ancient culture of the East. The article analyzes the widespread pervasiveness of Indian Buddhism as a source of Indian soft power in three countries in Northeast Asia - Japan, South Korea, and China as a concrete example for this.
\end{abstract}

\section{Introduction}

Buddhism originated in India but it has the ability to create its own place and vitality in different cultures. Buddhist has been adapting and integrating with the indigenous, selfreforming and directing activities to the secular life. Here we would like to mention the highly successful process of the Indian Buddhism reincarnation as an expression of the soft power of Indian Buddhism in many countries around the world. As such, the region cannot be ignored is the Northeast Asia with three typical countries, namely Japan, South Korea and China.

\section{Materials and methods}

The author uses the analysis methods to to point out the reasons why Indian Buddhism could be successfully reincarnated in the Northeast Asia with the case study of Buddhism in Japan, South Korea and China. The materials and methods used in this paper is to

*Corresponding author: thanhhanghh2015@gmail.com 
demonstrate that Indian Buddhism will help increase India's soft power resources in many countries around the world.

\section{Results}

\subsection{Buddhism reincarnation in Japan}

Buddhism was officially introduced to Japan in the $6^{\text {th }}$ century AD (around 538)[1]. This is Buddhism originating from India, developed in China and through Korea to Japan, so it bears all the characteristics of Chinese and Indian Buddhism [2]. Through many ups and downs of history and the process of colliding with Shinto - Japan's indigenous religion, the alien religion Buddhism still stands, gradually presents itself and exists firmly in the heart of Japan society because Buddhism has truly integrated into Japanese culture, attached to the country and people of Japan, becoming one of the important components contributing to the formation of Japanese culture.

In the context that Japan has a fairly solid religious tradition, in order to be accepted to exist, Buddhism has endeavored to reform itself, bringing out many changes to suit the mind, customs and lifestyle of citizen. Unlike other religions, which only recognize themselves as the unique and eliminate other religions, Buddhism deploys the motto "using all available means" to flexibly adapt to Japanese traditional religion and beliefs. Buddhism has imbued with Shinto, co-existing in harmony with it. This is considered a prominently noticeable feature in Japanese Buddhism. Upon each historical period, Shinto and Buddhism witnessed ups and downs but in general, they never engaged in vital opposition.

According to statistics in 2017, around 70 percent of the total population of Japan participated in Shinto practices. Closely behind is Buddhism, with more than 69 percent of the population adhering to its practices. Most Japanese thus practice both religions. The table 1 below shows percentage of believers in Japan in 2017.

Table 1. Distribution of believers by religion in Japan (Source: http://statista.com).

\begin{tabular}{|c|c|}
\hline Religions & Percentage of believers \\
\hline Shintonism & $70.4 \%$ \\
\hline Buddhism & $69.8 \%$ \\
\hline Christianity & $1.5 \%$ \\
\hline Others & $6.9 \%$ \\
\hline
\end{tabular}

Japanese Buddhism is divided into many sects. Statistically, Japan had 28 sects in 1939 and increased to 157 in 2001 [2]. Typical sects are many. In addition, there are new congregations in Japanese Buddhism. Despite the conflict between traditional conservative Buddhism factions and the radical ones, Japanese Buddhism has always been a very large social force - over half of Japan population is devout followers of Buddhism. They contribute to Japanese society in many ways such as morality, economic activity, social charity and peace struggle movements. Maintaining the tradition of reincarnation from the very beginning, Japanese Buddhist sects in the new era continue to stick with human life, expressing a deep secular spirit.

\subsubsection{In term of ethics and the way of life}

With the philosophy of compassion, joy, and morality education, Buddhism contributes to building and shaping the Japanese spirit, perfecting their personality and lifestyle. Naturally, Buddhism has become a moral tool and standard for behavior in Japanese society. Buddhist teachings not only have an impact on Buddhists and the masses of 
believers but also have the power to spread to the mass in society. It creates the spiritual power for the Japanese people to overcome the temptations of greed, hatred and delusion as well as reducing altruism and leading a selfless, compassionate lifestyle, eliminating all conflicts, violence in society.

The teachings, rituals and methods of Buddhist practice have entered the life of Japanese people for long, becoming their social habits, customs, habits and lifestyles. For example, the practice of meditation in Buddhism is accepted by the Japanese people as a way to improve health, help focus better on work, overcome misleading behaviors that cause conflicts and divisions. Meditation has even become a universal way of behaving in all social life, from ideology, morality, lifestyle to production and business activities.

The Zen spirit of Buddhism also combines smoothly with the tea drinking habits of the Japanese people to create a unique art imbued with the chanoyu (Japanese tea ceremony). Such ceremony imprints the spirit of Zen Buddhism with the noble philosophy of human life. It inspires elegance, youth, and harmony with nature to cultivate the mind and mind to attain enlightenment. The respectful and sacred rite of chanoyu gives us a sense of pilgrimage to return to the land of Buddha.

Similarly, another harmonious combination between Zen Buddhism and Japanese tree planting is bonsai art. This unique art of bonsai helps create beautiful shaped trees, expressing aesthetic tendencies, love, closeness and harmony with nature. It also embodies a profound philosophy of human life and humanity, purifying the soul, directing people to beauty, the noble and the moral values of life.

Obviously, Buddhism has contributed to the formation of universal moral standards and values in Japanese society, creating a unique Japanese lifestyle.

\subsubsection{In terms of economics}

Before 1945, with the maintenance of the principle of "Saisei Itchi", religion was thoroughly used by the Japanese authorities as a tool for the domination. After World War II, Japan completely failed, the US-led allied army made important decisions to change the direction of Japan development. In the field of religion, the Shinto that has lasted for centuries in Japan was dissolved: it instead implemented the principle of religious freedom, separating religion from the state. Since then, religions are not involved in politics and have a certain right to self-determination in terms of ideological and spiritual activities. This opens up new development opportunities for religions in general and Buddhism in particular but also poses many challenges because they used to be sponsored by the Government, especially in the context of extremely difficult restoration of the World War II devastation.

For Buddhism, many pagodas were destroyed, thousands of monks were killed through World War II. Although facing this difficulty and losing the main source of income of the pagoda following land reform, Buddhism was determined to restore its position as it used to have in history. The Law of Religious Juridical Person (宗教法人法) promulgated in 1951 was an important milestone for Buddhist organizations to enter into economic activities, promote lawful production and business to rebuild pagodas and install Buddhist ritual feast back to pagodas.

Today, in the strong process of urbanization and modernization in Japanese society, Buddhism is still very flexible to keep up with the changes. The changing social conditions force many Buddhists move to big cities and they no longer closely connect with the old pagodas in their homeland, families also have less time to regularly visit temples rather than on ritual occasions. Buddhism has renovated the way of living, using a few rooms of the apartment as a religious practice place that makes convenience for Buddhists. Suffering fewer and fewer tourists visiting pagodas, Buddhists turn the temple grounds into parking 
lots or venues for cultural and social events to collect money, deploy high-rise projects as a sanctuary for religious activities and a service location for rent. Besides, Buddhism also improve economy through missionary activities, organize festivals such as Obon, Higan, perform funeral and wedding services up to the Buddhist tradition, and give spiritual counseling services via telephone, etc [3]. Buddhist economic activities have gone beyond the scope of the temple and adapt to the daily life of the Japanese people.

\subsubsection{In terms of relief, humanitarian charity}

"Saving humanity" is the noble purpose of Indian Buddhism. When it was introduced into Japan, humanitarian and charitable activities soon became a tradition, a special strength of Buddhist organizations in Japan. In history, especially during the Edo or Tokugawa period (1600-1868), Buddhist monks were always willing to participate in community activities such as running schools or supporting community infrastructure projects. Entering the Meiji era, with the penetration of Western ideology and the existential risk of the traditional social role of monks and temples, Buddhism quickly launched a model of modern social welfare, such as the establishment of nursing centers, kindergartens at the temple's campus to meet the essential needs of Japanese society at that time [4].

Today, Japanese Buddhist organizations continue to build a social welfare system, including 116 Buddhist nursing homes, 26 rescue homes, 3 disabled homes; In addition, there are 220 child welfare facilities, 38 libraries, 49 museums [5]. Japanese Buddhist monks are also actively involved in teaching activities, social activities such as participation in educating prisoners in cells, protecting human rights, and fostering the movement for world peace ... Besides, Buddhist organizations are also conscious of and pay attention to relief of tsunami and nuclear disasters, carry out investment in aid, develop vocational training schemes, with special emphasis on developing Japanese traditional crafts.

\subsection{Buddhism reincarnation in Korea}

Korea is also one of the countries deeply influenced by Buddhism. Korean Buddhism was introduced from China, and it has a history of about 1700 years. According to recent statistics, Korea now has about 50 million people, of which 20 million are Buddhists with 20,000 Buddhist monasteries nationwide [6]. Through the process of missionary and dissemination, Buddhism has been rooted in the traditional culture of Korea, forming characteristics in Korean culture. Although Protestantism enjoys the leading religious number of followers in the developed country Korea, it is actually a new religion because it was introduced to Korea in the $19^{\text {th }}$ century. It can be said that religion really sticks to the ups and downs of Korean history, plays a crucial role in the social, cultural, spiritual and religious life of the Korean people, of which Buddhism is profound.

The table 2 below provides data about percentage of the total population participated in religions in South Korea in 2015.

Table 2. Distribution of believers by religion in Korea (Souce: https://en.wikipedia.org).

\begin{tabular}{|c|c|}
\hline Religions & Percentage of believers \\
\hline Protestantism & $19.7 \%$ \\
\hline Korean Buddhism & $15.5 \%$ \\
\hline Catholicism & $7.9 \%$ \\
\hline Other & $0.8 \%$ \\
\hline
\end{tabular}

Like Japanese Buddhism, Korean Buddhism had several drastic changes from the beginning of its introduction to adapt to the local culture. Buddhism quickly merged with Korea's traditional belief and folk religion system, the Samanism, to coexist harmoniously. 
Buddhism in the development process always shows respect and equality with other faiths and religions, contribute to the development of Korean cultural history.

In the process of fluctuant development of the nation's history associated with the plight, Buddhism always upholds the patriotism, "defending the people", accompanying the country and all Koreans to shoulder the national liberation mission and struggle for peace and unification. The national interests and the religious interests have always united into a unified whole, in which the national interests are always put first. This explains why in the context that Korea had a fairly stable system of religions and beliefs, Buddhism was still able to integrate into life, maintain and develop, becoming an impossible spiritual fulcrum of people. Even to this day, when modern cultural and ideological flows are introduced into Korea, Buddhism still asserts its position and cultural strength in the hearts of the Korean people.

Currently, Korea has 18 sects of Buddhism originating from the four main sects of Zen Buddhism, Tantric Buddhism, Dharma Zen Buddhism and Huayan Zen Buddhism. Among the 18 sects, the most typical and the most influential are the Jogye-jong sect. This sect alone has 1.632 pagodas with branches throughout the country and abroad, and it has about 18,000 monks and nuns, alongside 6,000,000 Buddhists [7].

Entering a new era, the Europeanization process considered as a consequence of economic development process, industrialization and modernization in Korea with the strong challenges of Christianity has posed many crucial issues for Buddhism. In order to maintain its role and position, Korean Buddhism must adapt to the modernization needs of the country, it continues to integrate into the lives of the people to build up a happy and peaceful world. On the rise of all aspects, Korean Buddhism has actually shown a positive spirit of reincarnation in many aspects of social life over the years.

\subsubsection{In term of ethics and way of life}

In the period of modernization, facing the risk of degradation and erosion of social ethical values, Koreans always consider Buddhism as a spiritual fulcrum to help them cultivate, control their temper and mood. Buddhism teaches people to respect life, renounce violence, a sense of the power to hold their own destiny and not rely on the invisible supernatural power as the viewpoint of the indigenous Korean belief and religious system. The Buddhist concept of the law of cause and effect, karma brings a kind-hearted way of life in the minds of people, while helping to form the principle of living fully responsible for their destiny.

Buddhism comes into the life of the Korean people through a fairly typical form, Temple Stay, which is the experience of a monk's life at Buddhist monasteries. In the course, one is taught how to bow to Buddha, to chant, to meditate, to drink Zen tea, to the four statues of Buddhists, to practice qigong, yoga, to practice martial arts, to paint, to write sutras in Chinese characters. As a result, people reduce the mental stress of daily life in the hustle of modern society. Temple stay program is now becoming a valuable cultural asset of Korea, attracting more and more participation of Korean people and foreign tourists.

In terms of education, knowledge development

Right from the beginning of its introduction into Korea, Buddhism has upheld the tradition of studiousness, bringing systematic education programs. In ancient and medieval times, the names of Buddhist intellectuals were always known in academic activities, greatly contributing to the process of perfecting and developing advanced knowledge in Korea. By the Joseon Dynasty, when New Confucian followers held a leading position in academic research and education while monks and nuns were considered the lowest class in society, education still upheld the tradition of knowledge education and training inside Buddhist monasteries. 
Today, the tradition of education in Buddhist monasteries continues to be promoted. The most concrete evidence is that most Buddhist monasteries have built a system of kindergartens and primary schools. Buddhist monks have always played an important role in the universal education program. Korean Buddhism now has a complete education system at all levels nationwide from elementary, intermediate, college to university. Many Buddhist universities not only have branches in the provinces but are also expanded to major city centers. In addition, the programs of lectures, catechism studies, short-term Zen studies, etc. of Korean Buddhism are increasingly attracting the attention and participation of many officials, classes in society.

Noticeably, the Buddhist Institute - a Korean non-governmental Buddhist organization, has made a lot of contribution to Korean education. The Buddhist Institute focuses on establishing education centers, colleges and universities, which provide both secular and spiritual education programs with the goal of training educated people the sense of responsibility and good moral qualities consistent with modern civil society in Korea.

\subsubsection{In terms of humanitarian charity}

Korean Buddhist temples have long been known as the house for orphaned or abandoned children by their families. This has become routine. In modern society, this model of social welfare continues to be maintained and expanded to include poor and disadvantaged children. The centers of Buddhism such as Iri Boyukwon, Gaiseong Boyukwon and Hanguk Boyukwon, etc. provide children with accommodation so that they do not have to live in deprivation and without discrimination. Here, the children get universal education from primary to high school, they also get vocational, ethical courses and participate in social integration programs.

In addition to the well-being of children, Korean Buddhist organizations have actively participated in a range of modern society's issues such as medical assistance and healthcare, organizing dental examinations for farmers, helping distressed people in the hospital, implement poverty reduction and improve living conditions for people in rural areas, launch movements to contribute to the construction of public works such as parks, museums, fisheries cooperatives, etc.

\subsection{Buddhism reincarnation in China}

Buddhism was introduced to China from the first century AD, it has maintained and developed until now.

According to statistics in 2010, the number of believers of Buddhism in China accounts for about $18.2 \%$ of the total population in China. Table 3 below about percentage of believers of all religions in China.

Table 3. Distribution of believers by religion in China (Source: https://www.indexmundi.com).

\begin{tabular}{|c|c|}
\hline Religions & Percentage of believers \\
\hline Buddhist & $18.2 \%$ \\
\hline Christian & $5.1 \%$ \\
\hline Muslim & $1.8 \%$ \\
\hline folk religion & $21.9 \%$ \\
\hline Hindu & $<0.1 \%$ \\
\hline Jewish & $<0.1 \%$ \\
\hline Other & $0.7 \%$ (includes Daoist (Taoist)) \\
\hline
\end{tabular}

According to statistics of the Buddhist Association of China, there are an estimated 180,000 monks and nuns in China at present. Of which, about 120,000 monks and nuns 
belong to the Tibetan Buddhist organization (Tantric Buddhism), 8000 monks and nuns belong to the Venerable Buddhist organization in Yunnan region (Theravada Buddhism), the rest are more than 50,000 monks, nuns belonging to the Sino-Buddhist tradition (Mahāyāna) [8]. In the process of development, Buddhism has integrated smoothly with the main traditional indigenous religion of China to become one of the three indispensable parts of the Three religions (Confucianism, Taoism, Buddism). Buddhism has enriched the connotation of traditional Chinese culture. Today, Buddhism continues to demonstrate its vitality and eternal value in China with the process of reincarnation in many aspects of social life.

\subsubsection{In term of ethics and way of life}

Chinese Buddhism has contributed significantly to the construction, maintenance and perfection of moral and social norms, creating an orderly, stable, healthy and civilized social environment. Using Buddhist ethics as a political means was once advocated by Chinese leader Jiang Zemin. Buddhist ethics with its long history can contribute to curing social diseases and caring for a healthy life. Clearly, in the process of rapid social transformation, the downside of the market mechanism has seriously degraded the traditional moral standards systems. In this context, Buddhism strived to make explanations about the doctrine of its religion, along with that is a system of norms and ethical standards consistent with the strengthening of building socialist morality in China.

Buddhism has adopted specific activities, for example, opening refresher classes and lectures on traditional culture at Buddhist monasteries; distributing publications on filial piety to travelers across the country; organize New Year holidays to reflect the tradition of "respect the old" in the Chinese Buddhist spirit; thereby conducting traditional ethical education for the masses of believers and the people in society.

Chinese Buddhism also has a significant impact on the daily life of people like vegetarianism and meditation. In the modernization period, when the material life is improved significantly, people pay more attention to the appropriate way of living to regulate the mental state and keep the soul at peace. Buddhism advocates an attitude of peace, tolerance with the motto "purifying mind and ceasing desire". One of the Buddhist ways of practice is to meditate to regulate the mind, keep it pure, thereby creating a sense of relaxation, health promotion and spiritual maintenance. In China, Zen theory and meditation practice always attract the attention of the people because the attitude and the practice of meditation are effective methods for people to maintain a balanced mental state when faced with many pressures of life. Today, in Chinese Buddhist temples, meditation teaching classes and meditation training courses are welcomed and registered.

The vegetarianism in Buddhism also goes into the life of Chinese people as a good habit for health. Vegetarianism has been popular among Chinese dynasties in history. During the Eastern/Later Han Dynasty (25-220 AD), vegetarianism was not only prevalent among Buddhism monks but it was also well received by the people. During the Southern and Northern dynasties period, Buddhism was extremely prosperous, Emperor Wu of Liang especially worshiped the vegetarian. Today, entering a new era, when the hypertension, high blood fat, diabetes, liver disease spread, the vegetarianism in Buddhism promoted its role well. Vegetarian restaurants are growing more and more in big cities and commercial centers in China, reflecting the habits and needs of the abundant material society, aiming to be frugal, close, friendly with nature. 


\subsubsection{In terms of economics}

Prior to the land reforms that took place in the 1950s, the main source of income for Chinese Buddhist temples came primarily from their land, through land lease, house rentals, and other estate properties owned by the temples. In addition, an important source of revenue comes from religious activities such as preaching, organizing religious ceremonies and festivals, and donations from the religious masses.

However, during the land reform period, the Chinese State conducted the expropriation of the Buddhism temples in order to abolish the monarchy economy and make Chinese Buddhism grow, produce what they need. By the early 1980s, after the mistake of the Great Cultural Revolution (1966-1976), the State began to implement a policy of relaxation with religion, returning property to religious organizations, but in fact, very little temple land is returned. The main religious organizations get back their houses and the land on which the house is located. Therefore, the main source of revenue for Buddhist temples cannot depend on such limited land assets. Furthermore, due to the influence of the "leftist" view of religion after the Great Cultural Revolution, Buddhist activities were weakened, Buddhist rituals and preaching were also limited.

Facing this situation, in order to be economically autonomous and minimize dependence on the State's control policies, Mr. Zhao Puchu, the former President of the Buddhist Association of China, set out a policy of maintaining the balance between "meditation practice and agricultural production". Accordingly, the practice of comprehending meditation is to study Buddhism, practice and teaching. Agricultural production is understood as any production activity that benefits the society. Based on this view, Chinese Buddhism has proved extremely flexible, establishing a new economic system - "monastic economy", contributing to the economic development of Chinese society.

The reason, "monastic economy" has the opportunity to develop in the period of market economy in China because at present, most Buddhist temples are located in charming scenery, which attract a lot of domestic and foreign tourists. Many temples have longlasting cultural and well-known values worldwide with magnificent architecture and stupas, such as Potala palace in Tibet, ... These have become attractive Buddhist spiritual places, which attracts a large number of tourists, creating a large source of income not only for Buddhism's economic independence but also for supporting local economic development. Buddhist tourism is playing an increasingly important role in local tourism activities and economic development in these places.

Along with the entrance ticket, tourist services such as tea rooms, vegetarian restaurants, galleries, souvenir shops, photo shops, even hotels have made a fair amount of money for the temples. It can be seen that the prosperity of the "monastic economy" have contributed to the development of China's Buddhist economy, overcoming the situation of Buddhism bases solely on alms, merit, donations of individuals, social organizations and the Government to maintain activities. Economic independence has increased the lives of Buddhist monks, helping to restore monasteries, and makes a significant contribution to the common welfare of Chinese society.

\subsubsection{In terms of humanitarian charity}

From the past until now, Chinese Buddhism has always upheld the thought of "gratefulness, retribution" which is the repayment of "the four great gifts" - the gift of parents, the gift of sentient beings, the gift of national society and the gift of the Buddha. Buddhism thanks towards society through two specific means: preaching, in term of spirituality and giving charity, in term of materiality. Dissemination helps the believers feel happy in spirituality, 
charity focuses on disadvantaged groups in society, helping those directly in difficult circumstances. Over the years, Chinese Buddhism has made a positive contribution to social charity, participating in relief of natural disasters such as floods, earthquakes, droughts, forest fires, and establishing study promotion funds and health funds.

Along with the rapid development of the "monastic economy," Buddhist temples became independent in the economy and started large social welfare projects.

At YuFo Temple in Shanghai city, charitable activities during the "warm New Year's Eve" become a traditional activity that takes place every year to call for the attention of the social community to the disadvantaged and difficult areas that need help. Through the forms of art performances, painting exhibitions, calligraphy, Jade Buddha Temple has raised considerable sum for the city's charity fund.

At Kaiyuan Temple in Fuzhou city Fujian province, social charity activities have also been widely implemented. Kaiyuan Temple has established a "Study Encouragement Fund for Youth in Fuzhou city", and is expected to establish a "Medical Relief Fund for Monks and Elderly People in Fujian Province", building "Fujian Buddhism Acupuncture Hospital".

In addition, due to information from Buddhism Association of China in 2002, some typical pagodas in social charity such as Nanputuo Temple in Xiamen contributed a large funding source to the poor during 1994-2002; pagodas in Guangdong province spent significant funding source on social welfare activities during the years 1993-2002.

Below, we provide table 4 about 10 countries with the largest number of Buddhists in the world (according to Pew Research Center's data in December 2012) [19]. Through the table, we could confirm the fact that, Buddhism has really successfully reincarnated in the Northeast Asia in particular and in Asia in general.

Table 4. Share of Buddhist population in NorthEast Asia and Worldwide (Source: https://www.pewforum.org).

\begin{tabular}{|c|c|c|c|}
\hline Countries & Buddist population & $\begin{array}{c}\text { Percentage of } \\
\text { population that is } \\
\text { Buddishm }\end{array}$ & $\begin{array}{c}\text { Percentage of world } \\
\text { Buddhist population }\end{array}$ \\
\hline China & $244,130,000$ & $18.2 \%$ & $50.1 \%$ \\
\hline Thailand & $64,420,000$ & $93.2 \%$ & $13.2 \%$ \\
\hline Japan & $45,820,000$ & $36.2 \%$ & $9.4 \%$ \\
\hline Burma (Myanmar) & $38,410,000$ & $80.1 \%$ & $7.9 \%$ \\
\hline Sri Lanka & $14,450,000$ & $69.3 \%$ & $3.0 \%$ \\
\hline Vietnam & $14,380,000$ & $16.4 \%$ & $2.9 \%$ \\
\hline Cambodia & $13,690,000$ & $96.9 \%$ & $2.8 \%$ \\
\hline South Korea & $11,050,000$ & $22.9 \%$ & $2.3 \%$ \\
\hline India & $9,250,000$ & $0.8 \%$ & $1.9 \%$ \\
\hline Malaysia & $5,010,000$ & $17.7 \%$ & $1.0 \%$ \\
\hline
\end{tabular}

\section{Conclusion}

Examining the profound process of Buddhism's entry into Japan, Korea, China in some aspects of social life shows that the soft power of Indian Buddhism is making a noticeable influence in Northeast Asia. By reconciling with indigenous religions, Buddhism has absorbed and got a stable root in different cultures. We believe that, in the process of extensive globalization, Indian Buddhism will become a factor that will help increase India's soft power resources in many countries around the world, contributing to promoting Indian culture, build trust, affection, admiration and sustainable cooperation of many countries in Northeast Asia in particular and other regions in the world in general. 


\section{References}

1. Tran Thi My Hoa, Typical characteristics of Buddhism in Japan, http://cjs.inas.gov.vn

2. Pham Hong Thai, Religious life in Japan today (Social Sciences Publishing House, Hanoi, 2005)

3. Nguyen Ngoc Phuong Trang, History of Japanese Buddhism, http://cjs.inas.gov.vn

4. Nguyen Hiep, Understanding Japanese Reincarnation, Phap Luan journal (2007)

5. Bui Thanh Phuong, Nhat Vuong, About the path of integration and development of Buddhism in Japan, http://philosophy.vass.gov.vn

6. Prominent characteristics of Buddhism and Vesak in Korea, http:// www. daophatngaynay.com

7. Tran Truc Lam, Buddhism in Korea today, http://www.lebichson.org

8. Thich Nguyen Hiep, Current challenges of Buddhism in China today, http://hoavouu.com.

9. S.C. Berkwitz, Buddhism in World Cultures: Comparative Perspectives (ABCCLIO, Santa Barbara, CA, 2006)

10. D.N. Gellner, R. Gombrich, Buddhism, International Encyclopedia of the Social \& Behavioral Sciences (2015)

11. D. Stent, BEd, Buddhism, http://doi.org

12. Roger J. Corless, The vision of Buddhism: The space under the tree, (series: Visions of reality: Understanding religions) (Paragon House, New York, 1989)

13. D. Keown, Buddhism, Encyclopedia of Language \& Linguistics (Second Edition) (2006)

14. M.G. Wiltshire, Ascetic figures before and in early Buddhism: the emergence of Gautama as the Buddha (Mouton de Gruyter, Berlin, New York, 1990)

15. R.S. Cohen, Beyond Enlightenment: Buddhism, Religion, Modernity (Routlege, London, 2006)

16. S.C. Berkwitz, Buddhism in World Cultures: Comparative Perspectives (ABCCLIO, Santa Barbara, CA, 2006) ISBN: 1851097821.

17. D. Ryûken Williams, The Other Side of Zen: A Social History of Sôtô Zen Buddhism in Tokugawa Japan (Princeton University Press, Princeton, NJ, 2004) ISBN: 0691 119287

18. D.N. Gellner, Buddhism, International Encyclopedia of the Social \& Behavioral Sciences (2001)

19. E.J. Eitel, Handbook of Chinese Buddhism, being a Sanskrit-Chinese dictionary of Buddhist terms, words and expressions, with vocabularies of Buddhist terms in Pali, Singhalese, Siamese, Burmese, Tibetan, Mongolian and Japanese (Philo Press, Amsterdam, 1970) 